\title{
Strategi Komunikasi Bisnis Online Shop "Shoppe" Dalam Meningkatkan Penjualan
}

\author{
Fauziah ${ }^{\text {a, } 1, *}$ \\ a Universitas 17 Agustus 1945 Jakarta \\ 1 fauziah_yanis@yahoo.com* \\ * corresponding author
}

\section{ARTICLE INFO}

\section{Article history}

Received

Revised

Accepted

Keywords

Komunikasi Bisnis,

Onlne Shop,

Peningkatan Penjualan

\begin{abstract}
Belanja melalui online (online shop) merupakan cara lain belanja yang ditawarkan oleh teknologi komunikasi yaitu internet dengan berbagai kemudahan yang diberikan, seperti kemudahan waktu dalam melakukan pekerjaan tanpa harus bertatap muka terlebih dahulu. Para konsumen belanja melalui online dapat dengan mudah mengakses online shop yang diinginkan, melihat pilihan barang, harga yang akan dibelinya, mengetahui kualitas barang melalui komen pembelinya dan cara pembayarannya. Kemudahan dan keunggulan belanja melalui online yaitu prosesnya, konsumen hanya membuka web online shop memalui internet bisa langsung melakukan transaksi online. Shoppe adalah salah satu situs belanja online pendatang baru, jika dibandingkan dengan situs belanja online lainnya. Strategi komunikasi bisnis Shoppe melalui marketplace. Dengan memudahkan para penjual serta pembeli dalam berinteraksi melalui fitur live chatnya, Shoppe juga menyediakan banyak produk mulai dari gadget, fashion, kosmetik, elektronik, otomotif dan lain sebagainya .
\end{abstract}

\section{PENDAHULUAN}

Perkembangan bisnis saat ini sudah sangat berkembang pesat, sampai pada internet (media online). Sistem bisnis yang seperti ini sudah banyak digunakan oleh perusahaan-perusahaan multinasional sampai pada pedagang retail kecil. Sistem bisnis jual beli merupakan komoditi utama yang menggunakan cara seperti ini, dimana dengan sistem penjualan yang seperti ini sangat memudahkan target pasar membeli yang dibutuhkan tanpa harus mengunjungi toko atau tempat penjualannya.

Kementerian Komunikasi dan Informatika (Kemenkominfo) mengungkapkan pengguna internet di Indonesia saat ini mencapai 63 juta orang. Dari angka tersebut, 95 persennya menggunakan internet. Menurut Menkominfo nilai transaksi belanja online (e-commerce) tahun 2013 mengalami peningkatan mencapai nilai nominal Rp. 13 triliun. Pasar e-commerce di Indonesia akan terus mengalami peningkatan, berdasarkan riset yang dilakukan ICD yang berkantor pusat di London, pertumbuhannya 42\% dari tahun 2012 sampai 2015. Pencapaian angka ini melampaui malaysia sebesar 14\%, Thailand 22\%, dan Filipina 28\%. Hal tersebut sangat menggoda bagi sebagian investor, baik dalam maupun luar negeri dalam mengembangkan kegiatan pemasaran melalui online (Kominfo.go.id)

Berdasarkan hasil riset Wearesosial Hootsuite yang dirilis Januari 2019 pengguna media online di Indonesia mencapai 150 juta atau sebesar 56\% dari total populasi. Jumlah tersebut naik $20 \%$ dari survei sebelumnya. Besarnya pengguna internet di Indonesia merupakan potensi bagi ekonomi digital nasional, sehingga muncul e-commerce, toko online dan bisnis lainnya yang berbasis teknologi komunikasi/internet. Dan hal ini akan menjadi kekuatan ekonomi digital di kawasan Asia Tenggara. Bahkan pihak e-commerce mengembangkan aplikasi khusus belanja online yang dapat di download dan diinstal melalui smartphone. Aplikasi khusus ini membuat aktifitas belanja online semakin mudah dilakukan oleh siapa saja dan dimana saja, sehingga diharapkan dapat meningkatkan penjualan.

\section{(https://databoks.katadata.co.id/datapublish/2019/02/08/berapa-pengguna-media-sosial-indonesia)}

Internet menjadi alat pemasaran yang efektif dan ideal bagi pelaku bisnis online shop, karena menjangkau jutaan orang dan dapat digunakan untuk mengejar target pasar yang terdiri dari sekelompok individu tertentu. Hal ini, karena aktifitas penggunaan internet yang biasa dilakukan yaitu 24 jam dalam 7 hari sangat menarik bagi pelaku bisnis online dan tidak terdapat batasan geografis. Salah satu fasilitas yang 
ditawarkan oleh internet yaitu para pengguna jasa jual beli online dapat dengan mudah mengakses online shop yang diinginkan, melihat pilihan barang, harga yang akan dibelinya, mengetahui kualitas barang melalui komen pembelinya dan cara pembayarannya. Saat ini ada lebih kurang 5 online shop yang banyak dikunjungi yaitu: Shoppe, Lazada, Bukalapak, Blibli danTokopedia. (Marketeers.com,2017)

Seiring dengan pesatnya kemajuan transaksi lewat internet masih terdapat banyak kekurangan didalamnya yang menyebabkan kerugian bagi produsen maupun konsumen online. Semakin banyak pula pesaing online shop yang terlibat didalamnya sehingga dibutuhkan strategi komunikasi bisnis yang tepat sehingga produsen dan konsumen pun sama-sama mendapatkan keuntungan, selain peningkatan penjualan online shop tersebut.

Shoppe adalah salah satu situs belanja online pendatang baru, jika dibandingkan dengan situs belanja online lainnya. Kehadiran Shoppe di Indonesia mulai Desember 2015. Prestasi shoppe melalui marketplace nya adalah memalui promosi yang dalam waktu singkat pengguna shoppe tidak kalah banya daro para pesaing online shop lainnya. Chris Feng adalah tokoh penting dibalik sejarah berdirinya Shoppe sekaligu juga CEO yang merupakan lulusan terbaik Universitas di Singapura.

Shoppe hadir dengan metode terintegrasi dengan dukungan logistik yang memiliki metode pembayaran yang aman dan nyaman. Sehingga membuat belanja online menjadi mudah, baik bagi penjual maupun pembeli. Kesuksesan Shoppe di Singapura diikuti dengan ekspansi Shoppe ke berbagai negara tetangga lainnya seperti Indonesia, Thailand, Malaysia, Vietnam, Taiwan dan Filipina. Shoppe diperkenalkan pertama kalinya sebagai pasar Customer to Customer (C2C) namun kemudian beralih menjadi model hibrid dan saat ini Shoppe dijadikan sebagai Business to Customer (B2C).

Sejak awal peluncurannya sebagai Shoppe Maal dan menjadi platform toko online yang memiliki brand ternama, kini Shoppe telah memiliki mitra bisnis mencapai lebih dari 70 penyedia layanan kurir terbaik yang ada diseluruh negara dan menyediakan berbagai dukungan logistik untuk semua penggunanya. shoppe juga telah meningkatkan kerjasamanya dengan berbagai jasa logistik lokal dan penyedia jasa transportasi online ternama dari berbagai negara. Hal ini merupakan bentuk kemajuan Shoppe yang selalu berupaya memberikan kesan terbaiknya untuk semua pengguna di berbagai negara, termasuk di Indonesia.

Shoppe cukup gencar dalam mempromosikan layanannya di Indonesia khususnya layanan bebas ongkos kirim, sehingga banyak minat konsumen. Selain itu, banyak upaya dilakukan Shopee untuk memperkecil jarak dengan e-commerce lain yang sudah bermain lama di Indonesia. Mulai dari kampanye mobile shopping10.10, penguatan pada komunitas penjualnya, dan strategi lainnya. Dengan program-program, kampanye, dan promosi yang dilakukan, Shoppe berhasil menduduki 5 besar e-commerce dengan jumlah pengunjung terbanyak.

Meskipun pemasaran melalui Internet sudah terjadi dimana-mana, namun tidak semua online shop menggunakan komunikasi bisnis melalui Internet dengan cara yang sama dan tepat sasaran. Strategi pemasaran melalui bisnis media online kenyatannya cukup sulit dalam menembus pasar di Indonesia. Hal ini disebabkan karena begitu banyak perbedaan konsumen di Indonesia mulai dari cara berbelanja, mengapresiasikan suatu produk, promosi penjualan, keadaan ekonomi, perbedaan budaya dan perkembangan teknologi menjadi tantangan tersendir bagi Online Shop, khususya Shoppe dalam menjangkau semua kalangan konsumen dan meningkatkan penjualan.

\section{Rumusan masalah}

Berdasarkan pemaparan diatas, maka rumusan masalah penelitian ini adalah "Bagaimana strategi komunikasi bisnis Online shop "Shoppe" dalam Meningkatkan Penjualan".

\section{Tujuan penelitian}

Tujuan dalam penelitian ini adalah untuk mengatahui Bagaimana Strategi Komunikasi Bisnis Online Shop "Shoppe" Dalam Meningkatkan Penjualan"

\section{KAJIAN LITERATUR}

\section{Media Online}

Perkembangan teknologi komunikasi atau internet yang begitu pesat saat ini telah melahirkan beragam bentuk media online, dimana media online merupakan situs yang dijadikan sebagai media untuk menyebarkan 
berbagai berita dan informasi. Melalui media online ini, berbagai berita maupun informasi dapat tersebar luas, lebih cepat, lebih terbuka dan lebih murah.

Ada tiga jenis media yang dapat dipergunakan dalam online marketing yaitu: media sendiri, media bersama dan media lain (advertsising site). Ketiganya memiliki karakteristik masing-masing. Menurut Faztrack (2008) media sendiri adalah media yang dibuat oleh perusahan atu brand. Isi teks, grafik dan segala macamnya bisa diatur sesuai dengan keinginan perusahaan. (Faztrack, 2008:57)

Media bersama (social media) adalah media yang dibangun oleh suatu pihak untuk orang banyak dengan kebijakan tersendiri. Ciri khas media ini adalah gratis (tanpa dikenakan biaya untuk penggunaannya) dan bersifat interaktif-komunikatif. Ketentuan konten yang dapat ditampilkan harus disesuaikan dengan aturan atau TOS pemilik media. Sementara media media iklan (advertising sites) adaah media yang mengkhususkan diri untuk penyebar iklan dalam dunia maya, biasanya iklan tersebut berbayar dengan ketentuan bahwa marketer dapat mengatur sepenuhnya konten. Target dan market yang ingin dituju. (Faztrack, 2008)

Social media adalah satu-satunya media interaktif dimana siapapun dapat memberikan konten baik review buruk ataupun menjelekan promosi yang sedang di publikasikan. Sementara itu media sosial inilah yang merupakan pasar dengan jumlah terbesar dalam dunia maya. Maka kemampuan mengendalikan media sosial adalah kunci keberhasilan online marketing sesungguhnya.

\section{Karakteristik Media Online}

Karakteristik yang dimiliki media online menurut Almisbahi (2012) adalah:

1. real time artinya berita, kisa-kisah, peristiwa dapat langsung dipublikasikan pada saat kejadian berlangsung/

2. interaktif, artinya pengguna atau pembaca dapat menikmati secara efisien dan efektif namun tetap terjaga dan didorong mendapatkan pendalaman dan titik pandang yang lebih luas bahkan berbeda. Selain itu adanya umpan balik (feed back) dari pembaca yang membaca sebuah berita melalui komentar yang disajikan dibawah berita yang ditampilkan.

3. Unsur-unsur media, dimana media online dapat menyajikan bentuk dan isi publikasi yang lebih kaya dalam sebuah web.

4. Kemudahan bagi pembuat dan penerbit berita dan pembaca untuk dapat mengakses dan menyimpan artikel yang diinginkan. Hal ini berkaitan denfan kemajuan dan kecanggihan teknologi komunikasi

\section{Bisnis Online}

Definisi bisnis online menurut Dwimarta dapat diartikan sebagai sebuah kegiatan bisnis yang dilakukan secara online dengan menggunakan perangkat komputer yang terkoneksi ke jaringan internet. Lebih jauh, " bisnis online merupakan kegiatan bisnis yang memanfaatkan jaringan internet ". Jadi jika memiliki sebuah komputer plus jaringan koneksi, adalah sebuah modal yang sangat cukup untuk memulai bisnis online. Bisnis online merupakan sebuah konsep, ide atau gagasan tentang cara bertransaksi yang praktis dan mudah dengan memanfaatkan teknologi internet. (Dwimarta, 2010)

Internet mampu menyediakan informasi bagi pengguna internet yang dibutuhkan para pelaku bisnis maupun personal. Mereka menggunakan internet sebagai media yang ampuh untuk mengkomersilkan dan promosi atas produk mereka dengan harapan bahwa pengguna internet dapat melihat dan mengenal hingga akhirnya tertarik menggunakan produknya. (Dwimarta,2010)

Menurut Dwimarta (2010) ada tiga tingkatan dalam interaksi bisnis online yaitu :

Tingkat pertama dari interaksi adalah satu ke banyak orang ( one to many), hubungan ini ke interaksi " seluruh pelanggan ". Walaupun tidak cukup identitas pelanggan, situs menyediakan informasi mendalam yang sama mengenai produk kepada seluruh pengunjung. Ketika pengguna mampu mengikuti jalan unik melalui materi , semuanya menerima " siaran " yang sama.

Tingkat kedua adalah dengan mengirim informasi yang dituju dan yang dibutuhkan. Situs dibangun yang menyediakan informasi, produk, dan bahasa yang dibutuhkan tiap kelompok dari pelanggan. Pendekatan ini mirip dengan pemasaran langsung, dimana pengiriman surat yang ditargetkan dikirim ke daftar pelanggan khusus dengan perilaku pembelian serupa. 
Tingkat yang ketiga adalah komunikasi langsung tetapi tidak interaktif. Dan Dialog interaktif one toone adalah langkah terakhir. Sementara sebagian besar informasi masih mengalir dari pemasar ke pelanggan, umpan balik dan dialog masih memungkinkan.

\section{Strategi Bisnis Online}

Bisnis online terus mengalami kemajuan, saat ini tidak hanya menggunakan website namun juga email dan aplikasi lainnya yang ada di internet. Ada beberapa hal yang harus dilakukan untuk menjadi bagian dari marketing agar dapat dikerjkan dengan sistem online marketing yaitu online advertising. Maraknya online marketing yang terjadi saat ini beriklan melalui website dengan memanfaatkan internet dalam aktivitasnya (Faztrack, 2008)

Internet dijadikan sebagai bagian dari marketing mix dengan pendekatan yang berbeda dari karakteristik media dan konsumen yang dijadikan target sasarannya. Langkah yang biasa digunakan dalam beriklan di internet adalah dengan memasang banner, namun langkah tersebut saat ini kurang efektif, karena tuntutan komunikasi dalam startegi pemasaran semakin beragam. Oleh karen itu, maka dibutuhkan strategi dan kreatifitas dalam strategi pemasaran dengan menggunakan media online. Sebagai contoh yaitu startegiviral melalui email marketing, membangun situs khusus dari produk yang terpisah dengan corporate site-nya, merancang webtorial pages, membuat advert gaming dan online survey. (Faztrack,2008)

Selain itu teknik advertising dalam online marketing yang lebih mudah dapat dilakukan menggunakan Search Engine Optimization (SEO). Saat ini sudah banyak para pengguna internet yang memanfaatkan SEO dan hampir $80 \%$ pengunjungnya melakukan pencarian data dengan mesin pencari ini. Selain itu dengan menggunakan online marketing diharapkan target market campaign yang dilakukan dapat tercapat dengan pendekatan secara efektif dan efisien. (Faztrack, 2008)

\section{Proses Online Business}

Secara umum, e-commerce dapat didefinisikan sebagai segala bentuk transaksi perdagangan atau perniagaan barang dan jasa dengan menggunakan media elektronik.. Media elektronik yang popular digunakan saat ini adalah internet. Proses yang terjadi pada bisnis online yaitu e-commerce, dimana para pihak yang melakukan kegiatan perdagangan atau perniagaan hanya berhubungan melalui suatu jaringan publik (public network) yang dalam perkembangan terakhir menggunakan media internet. (Saputro, 2012)

E-commerce adalah kegiatan-kegiatan bisnis yang menghubungkan perusahaan, konsumen dan suatu komunitas melalui transaksi elektronik serta perdagangan barang, layanan dan informasi yang dilakukan secara elektronik. E- Commerce digunakan sebagai transaksi bisnis antara perusahaan yang satu dnegan perusahaan lainnya, antara perusahaan dengan pelanggan atau perusahaan dengan institusi yang bergerak dalam pelayanan publik. (Saputro, 2012:56)

\section{Teori E-Commerce}

Hanson (2012) menjelaskan bahwa e-commerce didefinisikan sebagai segala bentuk transaksi perdagangan atau perniagaan barang dan jasa dengan menggunakan media elektronik. Seiring dengan lepas landasnya perdagangan elektronik, ada perubahan dari sekedar memberi saran menuju terjadinya penjualan secara online. Walaupun pengaruh terhadap pembelian masih merupakan dampak online online terbesar, membuat penjualan adalah kategori pertumbuhan tertinggi. Pengaruh $e$-commerce adalah dampak dari jaringan atas semua pembelian yang dilakukan secara offline. Pengaruh e-commerce dapat muncul melalui situs web informasional manapun. Pengaruh e-commerce terjadi baik untuk penjualan barang kecil ( musik,

tiket, film ) dan barang besar ( mobil, rumah ). (Hanson,2012)

Internet merupakan faktor pendorong perkembangan e-commerce dan merupakan infrastruktur yang ideal untuk menjalankan bisnis online, sehingga istilah e-commerce identik dengan menjalankan bisnis di internet. (Surata,2015).

Saat ini pasar e-commerce menjadi tambang emas yang sangat menggoda bagi sebagian orang yang bisa melihat potensi pasar online (online marketing). Pertumbuhan ini didukung dengan data dari Menkominfo yang menyebutkan bahwa nilai transaksi e-commerce pada tahun 2013 sudah mencapai angka Rp. 130 triliun. (Surata,2015) 
Bisnis E-commerce jauh lebih besar daripada jumlah konsumen, tapi mengikuti pola yang sama pada pengaruh, pemesanan dan penjualan. E-commerce telah lepas landas. Ia meningkatkan peran strategis situs web, mengubah pola perilaku pembelian pada konsumen dan bisnis, dan memberi tekanan pada saluran distribusi tradisional. Munculnya situs menciptakan insentif untuk meningkatkan kinerja situs Web dan respon pelanggan. Situs $e$-commerce berinvestasi lebih banyak daripada situs tanpa $e$-commerce. Sebagaimana $e$ commerce mendorong perusahaan untuk berinvestasi pada kinerja situs, ia menciptakan insentif yang kuat untuk meningkatkan personalisasi penggunaan online.

E-commerce dan personalisasi memperkuat satu sama lain. Personalisasi mendorong pengunjung untuk kembali ke toko elektronik. pada saat yang sama, ecommercer menyediakan hubungan krusial dari individu ke individu. Yang fundamental bagi personalisasi yang efektif. Contoh yang bagus, yang ditiru oleh banyak pemasar industrial, adalah pendekatan segitiga Dell. Jumlah total pembelian komputer oleh perusahaan ( istilahnya, nilai harapan hidup pelanggan ) menentukan jumlah personalisasi yang disediakan Dell bagi perusahaan langganannya. Ini membangun dirinya sendiri, sehingga tingginya personalisasi yang dilakukan ekstranet Dell menyebabkan pembelian yang lebih banyak dan nilai masa hidup yang lebih tinggi. Semakin kuat hubungan $e$-commerce, semakin banyak sumber daya, insentif dan data yang tersedia untuk memperkuat personalisasi hubungan. Tingkat personalisasi yang tinggi muncul sebagai situs tambahan dan situs utama., konfigurasi khusus yang menghubungkan kebutuhan pelanggan yang sebenarnya dan pengaturan dukungan online dengan software, sistem pembelian, dan jadwal pengiriman kepada pelanggan. (Hanson, 2012)

\section{Langkah-Langkah E-Commerce ( Pembelian Ecommerce)}

Dalam teori E-commerce, terdapat langkah-langkah yang ditetapkan sesuai dengan penuturan Ward Hanson (2012), dimana situs Web menyediakan konsumen dengan informasi yang sulit dan mahal jika dicari dengan cara lain. Tidak ada metode lain yang lebih mudah untuk berinteraksi dan memperoleh kualitas dan kuantitas informasi tentang perusahaan, produk, dan layanan. Adopsi konsumen terhadap internet sebagai sarana komunikasi begitu cepat, sebagian karena fakta tidak adanya alternatif yang hampir sama.

Langkah-langkah E-commerce menurut Hanson (2012) yaitu :

1. Harga ( price ): pembelian online yang lebih murah daripada metode tradisional.

2. Jumlah Pilihan ( assortment ): ragam produk lebih sesuai dengan keinginan pembeli.

3. Kenyamanan ( convinience ): waktu, lokasi, dan proses pembelian lebih superior.

4. Hiburan ( entertainment ): membeli secara online seharusnya lebih menyenangkan daripada alternatif lain.

\section{E-Commerce B2c}

Istilah E-commerce B2C atau bisa disebut E-commerce Busines to cunsomer. Busines to Cunsomer dapat diartikan sebagai transaksi ritel dengan pembeli individual. Yang mana B2C ini menggambarkan transaksi perusahaan menawarkan barang atau jasa ke konsumen,seperti mekanisme toko online ( electronik shoping mall ) yaitu transaksi antar e-merchant dan e-customer. Dalam transaksi penjualan B2C ini merupakan transaksi tunggal atau dengan hanya satu transaksi saja, khususnya penjualan produk jadi ke konsumen akhir saja. Jika diperhatikan lebih seksama, transaksi B2C ini seperti transaksi konvensional pada umumnya, tetapi model transaksi ini berlaku di transaksi jual beli online.

E-commerce B2c menurut Fuadi (2010) mempunyai karakteristik, antara lain:

1. Servis yang diberikan bersifat umun, dimana informasi disebarluaskan untuk khalayak luas.

2. Servis diberikan berdasarkan permohonan ( on demand), cunsomer melakukan inisiatif dan produsen harus siap memberikan respon sesuai permohonan.

3. Pendekatan sering digunakan dimana diambil asumsi klien (consumer) menggunakan sistem yang minimal (berbasis web) dan processing (bussines procedure). (Fuadi, 2010,78)

\section{Online Shop}

Online shop atau bisnis online adalah proses pembelian barang atau jasa antara penjual dan pembeli tidak pernah bertemu atau melakukan kontak secara fisik, dimana barang yang diperjualbelikan ditawarkan melalui display dengan gambar yang ada di suatu website atau toko online. Kemudian pembeli dapat memilih barang yang diinginkan dan melakukan pembayaran kepada penjual melalui rekening bank yang bersangkutan, Setelah proses pembayaran di terima, kewajiban penjual adalah mengirim barang pesanan pembeli ke alamat tujuan. (Kotler \& Amstrong, 2001 dalam Hawkins, Mothersbaugh \& Best,2007) 
Terdapat beberapa faktor yang mempengaruhi belanja melalui media internet menurut Louis dan Kurtz (2007) yaitu : Model Marketing Mix dimana sistem pemasaran yang baik adalah sistem komuikasi pemasaran yang didalamnya terdiri dari berbagai unsur terpadu.

Perkembangan marketing mix menyebabkan para ahli memberikan pernyataan, sabagaimana pendapat yang diberikan oleh Louis and Kurtz (2007) yaitu: kebijaksanaan pemasaran dapat diklasifikasikan ke dalam 4 strategi, yaitu :

1. Product strategy yaitu kebijaksanaan dalam pemasaran yang meliputi desain kemasan, merek perusahaan, merek dagang, surat izin, jaminan barang, jaminan perusahaan,perputaran produk dan pengembangan produk baru.

2. Distributon strategy yaitu Kebijaksanaan pemasaran yang meliputi pendistribusian barang, saluran penjualan barang dan orang yang mengalami pendistribusian barang ke konsumen.

3. Promotional strategy Kebijiksanaan dalam pemasaran yang meiputi personal selling, advertsing dan sales promotion yang memberikan komunikasi efektif antara perusahaan dan target market.

4. Pricing Strategy yaitu kebijaksanaan dalam pemasaran yang meliputi metode penetapan harga yang menguntungkan perusahaan dan konsumen dengan peraturan pemerintah serta pendapat umum.

Dari uraian diatas dapat disimpulkan bahwa Marketing Mix adalah suatu bauran yang terdiri dari 4 variabel yaitu: Produk, Place, Price, Promotion. Dan batasan promosi pada dasarnya memiliki tujuan yang sama yaitu menjual. (Louis and Kurtz, 2007)

Sementara Stanton (2006) mengemukakan batasan promosi adalah sebagai berikut : Promosi adalah bahan pokok yang digunakan untuk menyampaikan atau membujuk pasar menerima produk dari suatu perusahaan.Batasan di atas dijelaskan bahwa promosi adalah unsur yang digunakan sebagai informasi dalam mempengaruhi atau membujuk konsumen, agar mereka tertarik untuk membeli. " Promosi sesungguhnya adalah merupakan kegiatan yang mempunyai tujuan meningkatkan kelebihan suatau perusahaan. Fungsi dari strategi komunikasi promosi adalah menyampaikan informasi yang membujuk dan mempengaruhi pengambilan keputusan konsumen. (Stanton, 2006)

\section{METODOLOGI PENELITIAN}

\section{Pendekatan penelitian}

Objek penelitian ini adalah situs belanja (online shop) Shoppe. Penelitian ini dilakukan dengan menggunakan desain penelitian deskriptif Kualitatif. Penelitian deskriptif dilakukan untuk mendapatkan gambaran atau diskripsi tentang strategi bisnis online yang dilakukan Shoppe dalam meningkatkan penjualan. Sedangkan analisis kualitatif sebagai prosedur penelitian yang menghasilkan data deskriptif yang dapat dianalisa. (Moleong,2002)

\section{Teknik Pengumpulan Data}

Prosedur pengumpulan data dilakukan dengan Observasi melalui online shop Shoppe dan penelitian kepustakaan. Jenis data yang dipergunakan bersifat kualitatif Laporan penelitian akan berisi data-data kutipan untuk memberi gambaran penyajian laporan tersebut. Informan yang diwawancarai adalah Rezki Yanuar sebagai admin seller Shoppe yang merespon dan aktif melayani pembeli dan calon pembeli di media online.

\section{Lokasi dan Jadwal Penelitian} Maret 2019

Lokasi penelitian pada online shop Shoppe. Jadwal penelitian dilakukan pada bulan Januari sampai

\section{Hasil Penelitian}

Hasil penelitian menunjukkan bahwa online shop Shoppe merupakan online shop pendatang baru yang paling banyak dicari pada tahun 2017, selain Lazada, Tokopedia, Bukalapak dan Blili yang terlebih dulu sudah muncul didunia e-commerce. Berikut dibawah ini tabel E-Commerce Inndonesia yang paling banyak dicari tahun 2017 : 


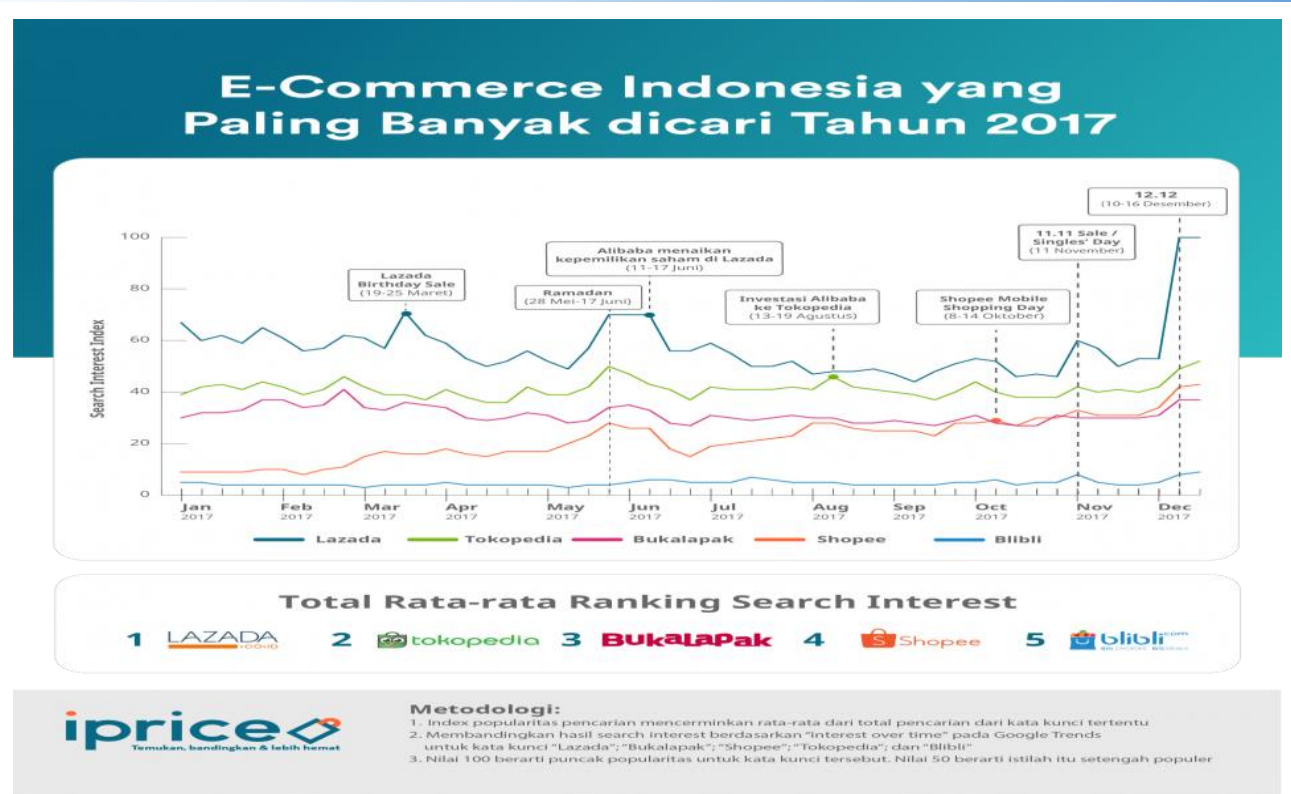

(Sumber : Iprice,2017)

Dari data yang diperoleh berdasarkan hasil survey iprice, Shoppe berada diposisi pertama sebagai aplikasi mobile terpopuler baik di platform Android maupun iOO. Hal tersebut mekungkinan besar berkat branding "toko Online C2C mobile" yang sering dilakukan sejak awal kemunculannya di Indonesia. Selain itu, program spesial lain yang dilakukan Shoppe tahun ini yaitu "Mobile Shopping Day" 10.10 dan saat ulang tahun Shoppe di bulan November.

Bagian admin seller Shoppe mengenai strategi komunikasi bisnis yang dilakukan Shoppe dalam meningkatkan penjualan diperoleh pernyataan bahwa :

1. Shoppe melakukan interaksi langsung dengan pembeli dan pelanggan dan menjalin relasi yang kuat bersama orang-orang yang mendukung Shoppe. Sehingga daftar seller Shoppe begitu banyak dan kompak.

2. Shopee memiliki tim sendiri untuk terjun ke lapangan dan menjumpai komunitas mereka di 16 kota. Bagi kota yang belum dijumpa, mereka melakukan video conference dan live streaming supaya informasi tetap berjalan baik.

3. Shoppe juga membuat komunitas Kampus Shopee, dimana sesama seller menjadi kenal satu sama lain sehingga dapat saling berbagi informasi seputar strategi penjualan dan sebagainya. Selain itu, mereka juga rutin mengadakan kegiatan menyenangkan lain yang membuat komunitas semakin lengket dan kompak. Pada saat ini Kampus Shopee telah menjangkau di 515 kota dan kabupaten di Indonesia dan 16 komunitas offline yang rutin mengadakan kegiatan setiap dua minggu sekali.

Sementara pernyataan yang diperoleh melalui Rezki Yanuar sebagai Country Brand Manager Shopee mengenai Strategi Shopee dalam meningkatkan penjualan menunjukkan bahwa Shoppe melakukan :

1. Teknik strategi pemsaran dengan mengikuti tren dan penguatan brand, dengan menggunakan hal-hal yang sedang viral untuk dijadikan konten pemasarannya. Sehingga masyarakat jadi lebih mudah mengingat dengan brand nya. Seperti pada iklan Shopee yang menggunakan Jokowi kw dengan wording "Sepedanya mana?", masyarakat yang sudah akrab dengan ciri khas Pak Jokowi yang suka bag-bagi sepeda, sehingga iklan tersebut gampang diingat masyarakat. Dan iklan ini berhasil meraih kemenangan dalam kategori iklan paling berkesan dalam Bright Awards Indonesia pada tahun 2017.

2. Menggunakan media yang tepat. Sejak awal kemunculannya, Shopee memfokuskan bisnisnya kepada pengguna mobile phone. Brand ini kemudian dikenal sebagai pelopor aktivitas belanja melalui ponsel. Startegi ini diterapkan berdasarkan riset dari e-marketer yang menyebutkan pengguna ponsel di Indonesia berkembang pesat dibandingkan dengan negara lain di Asia Tenggara. Sesuai perkiraan, dari 200 ribu pesanan setiap harinya, 90\% diantaranya berasal dari aplikasi mobile phone. Yang dilakukan Shopee dalam hal ini adalah menggunakan informasi akurat sebagai landasan startegi bisnis, sehingga tepat sasaran. 
3. Promo irit selangit adalah senjata Shopee yang disukai banyak konsumen, sampai saat ini Shopee masih memberikan promo gratis ongkos kirim bagi para penggunanya. omhkos kirim diberikan dengan batasan pembelian tertentu. Walaupun nominalnya tidak terlihat besar bagi calon konsumen namun gratis ongkos kirim menjadi daya tarik tersendiri.

4. Jaminan harga termurah. Untuk bisa bersaing dengan marketplace lainnya, Shopee menggunakan kampanye "Garansi harga Termurah, Unag kembali 2x Lipat". Jaminan inilah yang membuat pengguna Shopee tidak lama berpikir untuk terus melakukan transaksi.

5. Punya target pasar yang jelas. Target pasar Shopee adalah perempuan. Hal ini karena pengguna ecommerce di Indonesia didominasi oleh perempuan, terutama perempuan usia muda. Shopee fokus kepada kebutuhan-kebutuhan perempuan seperti produk kecantikan dan fashion.

\section{PEMBAHASAN}

Bisnis melalui media online tidak semudah yang dibayangkan, apalagi startegi komunikasi bisnis yang akan dilakukan untuk meningkatkan penjualan. kebijaksanaan pemasaran dapat diklasifikasikan ke dalam 4 (empat) strategi, yaitu: (Louis, Kurtz, 2007)

Strategi produk (Product Strategy) yaitu kebijaksanaan pemasaran yang dilakukan Shopee yaitu dengan mendesain kemasan sehingga menjadi lebih menarik tampilannya, menbranding merek Shopee dengan online shop lainnya, membuat merek dagang, surat izin, membuat jaminan barang, jaminan perusahaan dan perputaran produk. Dalam hal ini memperkuat brand dan tren yang sedang berkembang adalah strategi yang harus dilakukan Shoppe, karena tanpa brand yang kuat dan mengikuti tren, maka persaingan akan langsung mengarah ke satu titik, yaitu persaingan harga. Jika sudah terjadi seperti itu, maka tidak dapat berharap banyak untuk peningkatan penjualan. Selain itu, dengan membangun brand yang baik, maka dengan mudah dapat keluar dari persaingan harga. Harga yang ditawarkanpun dapat lebih timggi dan persaingan dapat dialihkan ke kualitas produk atau kualitas pelayanan Shoppe.

Distribution strategy yaitu kebijaksanaan pemsaran yang meliputi pendistribusian barang, saluran penjualan barang, saluran penjualan barang dan orang yang mengalami pendistribusian barang ke konsumen. Strategi distibusi yang dilakukan Shoppe yaitu memperbanyak metode penjualan dengan melakukan konversi kepada konsumen. Dengan strategi ini diharapkan antara pembeli dan penjual tidak dibatasi waktu dan tempat. Transaksi yang dilakukan lintas daerah dapat dilakukan dengan mudah cukup dengan menggunakan mobile phone (gadget) Selain itu, Shoppe juga memiliki target pasar yang jelas yaitu perempuan, sehingga Shopee berfokus kepada kebutuhan-kebutuhan perempuan seperti produk kecantikan dan fashion yang sedang up to date atau kekinian.

Promotional strategy yaitu kebijaksanaan dalam pemasaran yang meliputi personal selling, advertising dan sales promotion yang memberikan komunikasi yang efektif antara perusahaan dan target market. Promosi yang dilakukan online shop Shoppe adalah efektif dan tepat sasaran. Promosi yang efektif menjadi bagian yang sangat penting dalam untuk mengikat calon konsumen. Selain itu, akan mampu membuat pelanggan tertarik dengan produk ditawarkan, dan akhirnya membeli, sehingga Shopee akan menghasilakn keuntungan yang berlipat ganda. Seperti promo "Irit Hasil Selangit" dan gratis ongkos kirim adalah senjata Shopee yang disukai banyak konsumen.

Strategi harga (pricing startegy) adalah kebijaksanaan yang dilakukan Shopee dalam pemasarannya yang meliputi metode penetapan harga yang menguntungkan bagi Shopee dan konsumen dengan pertimbangan peraturan pemerintah. Selain itu jaminan harga termurah adalah faktor yang menjadi pertimbaangan konsumen sebelum membeli. Pasang harga dengan percaya diri inilah yang menjadi daya tarik online shop Shoppe, sehingga dapat bersaing dengan lima online shop terlengkap dan terlaris lainnya. Shoppe menjual produknya yang berkualitas, sehingga Shoppe percaya diri dalam memberikan harga.

Strategi komunikasi bisnis yang dilakukan Shoppe juga adalah memberikan pelayanan terbaik kepada pelanggan dengan memberikan info yang detail tentang harga, kualitas produk, spesifikasi, garansi dan yang lainnya dengan pelayanan yang terbaik. Selain itu, Free Delivery (gratis ongkos kirim) adalah salah satu metode pelayanan kepada pelanggan yang dilakukan Shoppe. Teknik ini cukup ampuh digunakan untuk menarik konsumen membeli produk kita. Shoppe, adalah salah satu online shop yang menggunakan metode ini. Peningkatan kualitas pelayanan menjadi nomor satu bagi Shoppe. Setiap pengunjung diposisikan seperti seorang raja. Segala keluhan akan diselesaikan dengan sebaik-baiknya. Shoppe juga meminta data konsumen

Fauziah (Strategi Komunikasi Bisnis Online Shop “Shopee” Dalam Meningkatkan Penjualan ...) 
seperti nomor handphone, supaya dapat selalu menyampaikan apabila ada produk baru atau diskon promo kepada pelanggan. Dan Shoppe juga selalu merespon pembeli dan pelanggan dengan meminta maaf dengan baik kepada pelanggan, apabila terjadi kesalahan dalam pengiriman produk, produk tidak sesuai dengan yang diinginkan pembeli dan lain-lain. Shoppe berharap pelanggan akan semakin loyal. Maka tidak mengherankan apabila Shoppe sebagai pendatang baru di dunia retail online dapat bersaing dengan online shop lainnya bahkan terlaris dan terdepan jika dibandingkan dengan online shop lainnya.

\section{KESIMPULAN}

Dari hasil penelitian dapat disimpulkan bahwa :

1. Strategi yang dilakukan Shopee adalah melakukan teknik pemsaran yang mengikuti tren dan penguatan branding. Selain itu Shopee menggunakan hal-hal yang sedang viral atau tren untuk meateri konten pemsarannya. Sehingga masyarakat atau pengguna lebih mudah mudang ingat dengan brand Shopee.

2. Shoppe memiliki target pasar yang jelas yaitu perempuan, sehingga Shopee fokus pada kebutuhankebutuhan perempuan seperti peroduk kecantikan dan fashion.

3. Shoppe memberikan promosi yang efektif dan tepat sasaran untuk mengikat calon pembeli.

4. Shopee menggunakan slogan kampanye "Garansi Harga Termurah, Uang Kembali 2x Lipat". Pasang harga dengan percaya diri inilah yang menjadi daya tarik online shop Shoppe, sehingga dapat bersaing dengan lima online shop terlengkap dan terlaris lainnya

\section{DAFTAR PUSTAKA}

Kotler, Philip. \& Amstrong, Gary, 2001, Principles of Marketing. 6th Edition. New Jersey: Prentice Hall Kennedy, John. E; R Dermawan Soemanagara., 2006. Marketing Communication -Taktik dan Strategi. Jakarta. PT Buana Ilmu Populer (kelompok Gramedia)

Moleong, Lexy, 2002. Metodologi Penelitian Kualitatif. Bandung: Remaja Rosdakarya

David Dwimarta, 2010, Bisnis Online, Yogyakarta, Penerbit : Kata Buku

M, Suyanto, 2003, Strategi Periklanan E-commerce pada Perusahaan Top Dunia, Yogyakarta : Andi

Boone, Louis E \& Kurtz, David L. 2007. Contemporary Business, buku 1. Jakarta: Salemba Empat.

Stanton, William J 2008, Management of a Sales Force, Penerbit : Boston : McGraw-Hill

\section{Jurnal :}

Haubl, G \& Trifts, V, 2000, Customer Decision Making in Online Shopping Environments: The Effects of Interactive Decision Aids. Marketing Science. Vol.19 (1): 4-21

Liang, T \& Lai, H, 2000, Electronic Store Design and Consumer Choice: An Empirical Study. Proceedings of The 33rd Hawaii International Conference on System Science.

\section{Internet}

https://databoks.katadata.co.id/datapublish/2019/02/08/berapa-pengguna-media-sosial-indonesia

Awaluddin, Yusuf, Iwan 2012, Pengertian Media Online, dalam http://bincangmedia.wordpress.com/tag/pengertian-media-online/, 18:00

Faztrack, 2008, Jenis Media dalam Online Marketing, dalam http://gofaztrack.com/sales/jenis-media-dalamonline-marketing/, 18:00

Faztrack, 20078, Strategi Online Marketing, dalam http://gofaztrack.com/sales/onlinemarketing-strategimarketing-modern/, 18:00.

Itha-Almisbahi, 2012, Perbedaan Karakteristik Media Online dalam http://arexsedoarejo perbedaan karakateristik media online html. 18.00

Hendra W Saputro, 2012,Tantangan Komunikasi Bisnis di Masa Depan, dalam http://www.baliorange.web.id/Tantangan Komunikasi Bisnis-yang Akan Datang/, 19:00.

Munir Fuadi, 2010 Teori E-commcerce, dalam http://cun2 inside.blogspot.com/2010/08/teori-ecommerce.html/, 20:00

WWW. Marketeers.com,2017

Kominfo.go.id, 2016 